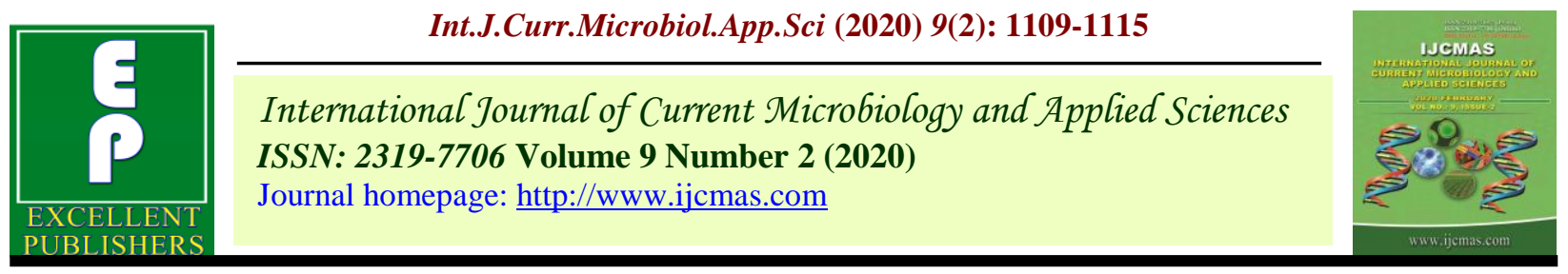

Original Research Article

https://doi.org/10.20546/ijcmas.2020.902.129

\title{
Attracting and Retaining Youth in Agriculture - A Case of Agriclinics and Agribusiness Centres (ACABC) Scheme in India
}

\author{
G. B. Chaitra ${ }^{1^{*}}$, Chidanand Patil ${ }^{2}$ and R. A. Yeledhalli ${ }^{3}$ \\ ${ }^{1}$ Department of Management Studies, Malwa College, Bathinda, Punjab - 151001, India \\ ${ }^{2}$ Department of Applied Agriculture, Central University of Punjab, \\ Bathinda, Punjab - 151001, India \\ ${ }^{3}$ Department of Agribusiness Management, College of Agriculture, University of Agricultural \\ Sciences, Dharwad, Karnataka, India \\ *Corresponding author
}

\section{A B S T R A C T}

\section{Keywords}

Agriclinics and Agribusiness Centres, Agrientrepreneurship, Employment

Article Info

Accepted:

08 January 2020

Available Online:

10 February 2020

\begin{abstract}
The subsidy based credit linked Agriclinic and Agribusiness Centres (ACABC) scheme was launched in the year 2002 with an objective of providing employment opportunities to the agricultural graduates and also for strengthening the agricultural extension services to the farmers with the support of National Bank for Agriculture and Rural Development (NABARD). The findings of the study revealed that the number of trained candidates under the ACABC scheme has increased from 2400 in 2002 to 6600 in 2019 and also the number of agri-ventures established by the trained graduates has increased from 416 in the year 2002 to 2393 in the year 2019. The performance of the ACABC scheme was better in the states of Maharashtra, Uttar Pradesh and Tamil Nadu, while the scheme could not yield effective results in training candidates from north-eastern states of the country. On an average the success rate of agri-ventures established by the trained graduates was 41 percent. There is a requirement of little more emphasis towards operation of scheme in north eastern states of the country for improving the agri-entrepreneurship opportunities of the agriculture graduates of that region.
\end{abstract}

\section{Introduction}

Agriculture sector is the primary source of livelihood for 58 percent of population in India and gross value added by agriculture, forestry and fishing was estimated to be at 18.55 lakh crore in FY 2019 (IBEF Report, 2019). The growth in agriculture sector has been fluctuating as it had increased from -0.2 percent in 2014-15 to 6.3 percent during
2016-17, and then it declined to 2.9 percent in 2018-19 (Economic Survey, 2019). The gross capital formation in agriculture had decreased to 15.2 percent in $2017-18$ from 17.7 percent in 2013-14. India has three Central Agricultural Universities, four Deemed Universities and 64 State Agricultural Universities and every year thousands of agricultural graduates are coming out from all these universities. Rama Rao et al. (2011) 
revealed that the agricultural education system was admitting 39,300 candidates. Manikandan and Sheik Abdullah (2016) reported that the demand for trained agricultural human resource depends on sectoral growth and attrition rate of the existing employed stock. More than 15000 agricultural graduates pass-out from state agricultural universities (SAUs) every year, of which only about 2000 find job in private and public sector, leaving a huge number of graduates unemployed (Global Agri System, 2009).

In order to strengthen the existing agricultural extension services which are provided to farmers and at the same time to tap the potential of unemployed agriculture graduates by providing them the employment opportunities by making them the agripreneurs, the Union Finance Minister during the budget speech on February 28, 2002 had announced for setting up of Agriclinic and Agribusiness Centres $(\mathrm{ACABC})$ scheme by agriculture graduates with the support of National Bank for Agriculture and Rural Development (NABARD). The ACABC scheme was launched on April 9, 2002 to supplement the efforts of agricultural extension services in the country with the objectives of (1) providing extension services to farmers on payment basis (2) supplementing agriculture development and entrepreneurship and (3) promotion of self-employment in agriculture. The setting up of Agriclinic (AC) and AgriBusiness Centres $(\mathrm{ABC})$ by the agricultural graduates will help them to improve their income, provide a better position in society, strengthen the transfer of technology and extension services (Kantwat et al., 2011). The subsidy component under the ACABC scheme is 36 percent for General Category candidates and 44 percent to the women, SC/ST and north eastern and hill states candidates. The present study is an attempt to assess the performance of Agriclinics and Agribusiness Centres scheme in India.

\section{Materials and Methods}

The primary objective of the study is to evaluate the present situation and performance of the Agriclinics and Agribusiness Centres scheme in India. The present study was based on the secondary data collected from various journals, research studies, websites, etc. For studying the various issues relating to the performance of Agriclinics and Agribusiness Centres scheme a wide range of literature review was also conducted. The ultimate purpose of the study was to analyse the various aspects, issues and progress of the Agriclinics and Agribusiness Centres scheme on the basis of performance of across different states of the country.

The year-wise progress of ACABC scheme is depicted in Figure 1. It is clear from the figure that the number of trained candidates has increased from 416 during 2002-03 to 6600 in 2018-19. On the other hand the number of agri-ventures established also has increased from 416 in 2002-03 to 2393 in 2018-19. From the data it was clear that on an average 40.91 percent of the trained candidates had established their agri-ventures. Suitable strategies need to be adopted to encourage all trained candidates to establish their agriventures which will help in providing employment opportunities in rural areas and improving the agricultural sector of the country.

Parimaladevi et al. (2006) reported that the most important factors which influence the establishment of agribusiness units were attitude towards self-employment, entrepreneurial ability and self-confidence. Chahal and Ponnusamy (2014) revealed that the majority of female respondents did not venture into $\mathrm{ACABC}$ due to lack of family 
support, previous jobexperience and selfconfidence. They also mentioned that the prevailing societal attitude might had forced the females to avoid starting of an enterprise in their village due to fear of being criticized.

Table 1 shows the progress of ACABC schemes in different states and union territories in India. A total of 200 institutes across India were providing training to the candidates. From the table it is clear that a total of 69395 candidates have been trained from April 2002 to January, 2020 and a total of 28512 Agri-ventures have been established across various states and union territories in India. Maximum number of candidates were trained from the state of Maharashtra (17164) followed by Uttar Pradesh (15197) and Tamil Nadu (7445). While the scheme could not yield effective results in training candidates from union territories and north-eastern states of the country like Chandigarh (3), Tripura (5) and Sikkim (9). The number of agriventures established by the candidates after getting training from $\mathrm{ACABC}$ scheme was high in the state of Maharashtra (17164) followed by Uttar Pradesh (15197) and Tamil Nadu (7445). Whereas the agri-ventures establishment was poor in various northeastern states like Mizoram, Tripura and Sikkim, and Chandigarh.

Parimaladevi et al. (2006) reported that the agribusiness training programmes should focus on bringing the changes in attitude towards self-employment, developing entrepreneurial ability and enhancing selfconfidence of trainees, which will going to promote in establishing successful agriventures. Karjagi et al. (2009) revealed that heavy competition from well-established and other old dealers in business, farmers asking the products on credit basis and noncooperation of farmers were the major problems faced by the agripreuners in running their agriventure.
Venkattakumaret al. (2012) recommended that the nodal training institutes should improve the training aspects in terms of exposure visits, arranging interaction with successful agripreneurs, boarding and transport facilities, inculcating strategies for linkages and collaboration in business, extending handholding support after training and maintaining overall training seriousness. Chahal and Ponnusamy (2014) indicated that the success of ACABC scheme depends up on sensitization of family members, bank and development officials, more handholding and financial support, incentives and mass media support.

\section{Activity-wise progress of $\mathrm{ACABC}$ scheme}

It can be observed from Table 2 that a total of 28,512 agri-ventures have been established from April 2002 to January, 2020 under 32 different activities across different states in India under the ACABC scheme. The projects which top the list are Dairy/Poultry/Piggery/Goatary (9405) followed by Agri-Clinics and Agribusiness Centres (7964), Agri-Clinics (4567), Veterinary clinics (940) and farm machinery units (815). The agri-ventures which show less number of establishments include AgroEco Tourism (17), Fisheries clinic (17), Agriculture journalism (18) and Tissue culture unit (28). The projects relating to Dairy/Poultry/Piggery/Goatary are on the top of the list and the reason for this might be attributed to increase in demand for dairy products, egg and meat.

On an average the success rate of agriventures established by the trained graduates was 41 percent. Venkattakumar et al. (2016) reported that over 15000 agricultural graduates were under ACABC scheme but the success rate of establishment of agri-ventures by the trained graduates was only 35 percent. 
Table.1 Progress of Agriclinics And Agribusiness Centres Scheme from 01-04-2002 to 17-01-2020

\begin{tabular}{|c|c|c|c|}
\hline S.No. & Name of the State & $\begin{array}{c}\text { No. of Candidates } \\
\text { trained }\end{array}$ & $\begin{array}{l}\text { No. of Agri-ventures } \\
\text { established }\end{array}$ \\
\hline 1 & Andhra Pradesh & 1250 & 321 \\
\hline 2 & Arunachal Pradesh & 35 & 3 \\
\hline 3 & Assam & 754 & 227 \\
\hline 4 & Bihar & 4031 & 1392 \\
\hline 5 & Chandigarh & 3 & 1 \\
\hline 6 & Chattisgarh & 808 & 335 \\
\hline 7 & Delhi & 34 & 6 \\
\hline 8 & Goa & 13 & 7 \\
\hline 9 & Gujarat & 1997 & 767 \\
\hline 10 & Haryana & 712 & 234 \\
\hline 11 & Himachal Pradesh & 421 & 108 \\
\hline 12 & Jammu and Kashmir & 1491 & 191 \\
\hline 13 & Jharkand & 771 & 186 \\
\hline 14 & Karnataka & 4046 & 1618 \\
\hline 15 & Kerala & 239 & 51 \\
\hline 16 & Madhya Pradesh & 3680 & 1329 \\
\hline 17 & Maharashtra & 17164 & 8062 \\
\hline 18 & Manipur & 439 & 128 \\
\hline 19 & Meghalaya & 35 & 3 \\
\hline 20 & Mizoram & 35 & 0 \\
\hline 21 & Nagaland & 184 & 21 \\
\hline 22 & Orissa & 624 & 114 \\
\hline 23 & Pondicherry & 136 & 84 \\
\hline 24 & Punjab & 662 & 218 \\
\hline 25 & Rajasthan & 3746 & 1387 \\
\hline 26 & Sikkim & 9 & 1 \\
\hline 27 & Telangana & 1771 & 419 \\
\hline 28 & Tamil Nadu & 7445 & 3689 \\
\hline 29 & Tripura & 5 & 1 \\
\hline 30 & Uttar Pradesh & 15197 & 7152 \\
\hline 31 & Uttaranchal & 471 & 161 \\
\hline \multirow[t]{2}{*}{32} & West Bengal & 1187 & 296 \\
\hline & Total & 69395 & 28512 \\
\hline
\end{tabular}


Table.2 Overview of projects established under ACABC scheme from 01-04-2002 to 17-012020

\begin{tabular}{|r|l|c|}
\hline S. No. & \multicolumn{1}{|c|}{ Project Description } & Number of ventures established \\
\hline $\mathbf{1}$ & Agri-Clinics & 4567 \\
\hline $\mathbf{2}$ & Agri-Clinics and Agribusiness Centres & 7964 \\
\hline $\mathbf{3}$ & Agro-Eco Tourism & 17 \\
\hline $\mathbf{4}$ & Animal Feed Unit & 59 \\
\hline $\mathbf{5}$ & Bio-fertilizer production and Marketing & 166 \\
\hline $\mathbf{6}$ & Contract Farming & 111 \\
\hline $\mathbf{7}$ & Cultivation of Medicinal Plants & 114 \\
\hline $\mathbf{8}$ & Direct Marketing & 171 \\
\hline $\mathbf{9}$ & Farm Machinery Unit & 815 \\
\hline $\mathbf{1 0}$ & Fisheries Development & 397 \\
\hline $\mathbf{1 1}$ & Floriculture & 111 \\
\hline $\mathbf{1 2}$ & Horticulture Clinic & 178 \\
\hline $\mathbf{1 3}$ & Landscaping + Nursery & 114 \\
\hline $\mathbf{1 4}$ & Nursery & 589 \\
\hline $\mathbf{1 5}$ & Organic production / Food chain & 117 \\
\hline $\mathbf{1 6}$ & Pesticides production and marketing & 57 \\
\hline $\mathbf{1 7}$ & Value addition & 422 \\
\hline $\mathbf{1 8}$ & Fisheries clinic & 17 \\
\hline $\mathbf{1 9}$ & Seed processing and marketing & 380 \\
\hline $\mathbf{2 0}$ & Soil testing laboratory & 110 \\
\hline $\mathbf{2 1}$ & Tissue culture unit & 28 \\
\hline $\mathbf{2 2}$ & Vegetable production and marketing & 405 \\
\hline $\mathbf{2 3}$ & Vermicomposting / Organic manure & 536 \\
\hline $\mathbf{2 4}$ & Veterinary clinics & 940 \\
\hline $\mathbf{2 5}$ & Crop production & 318 \\
\hline $\mathbf{2 6}$ & Dairy/Poultry/Piggery/Goatary & 9405 \\
\hline $\mathbf{2 7}$ & Rural godown & 58 \\
\hline $\mathbf{2 8}$ & Production and marketing of bio-control & 30 \\
\hline $\mathbf{2 9}$ & agents & 18 \\
\hline $\mathbf{3 0}$ & Sericulture journalism & 63 \\
\hline $\mathbf{3 1}$ & Mushroom cultivation & 131 \\
\hline $\mathbf{3 2}$ & Apiary & 104 \\
\hline & & $\mathbf{2 8 5 1 2}$ \\
\hline & & \\
\hline & & Total \\
\hline
\end{tabular}


High rate of interest and lack of subsidy component in the scheme, lack of handholding support from the training institutions and hesitation from bankers to finance were the major problems faced by the trained agricultural graduates in establishing their agriclinics and agribusiness centers (Karjagi et al., 2009).Venkattakumar et al. (2016) mentioned that the top three critical success factors of ACABC in India were satisfactory services to the customers, up-todate knowledge on latest innovations in the field and timely innovation of sector innovations.

In conclusion, the Agriclinics and Agribusiness Centres scheme is an effective scheme for providing employment opportunities to the agricultural graduates which will also help in improving the rural economy of India. There is a requirement of little more emphasis towards operation of scheme in north eastern states of the country. Karjagi (2006) recommended that the agriculture universities, research institutions and various supporting organizations should provide regular support and guidance to the agriculture graduates engaged in agri-business activities. Taufiq et al. (2016) highlighted that linking the financial institutions with training institutions, banks should follow the guidelines of RBI and private agri-clinics should be treated on par with the government agri-clinics were the the major suggestions provided by the agripreneurs.Kanwatet al. (2011) concluded that the moderately favourable attitude of the youth leads to the recommendation that still there is need to put more efforts to bring the youth under most favourable attitude toward the skill development.

\section{References}

Chahal, V. P. and Ponnusamy, K., 2014, Study on gender issues in promoting agri-entrepreneurship among farm

graduates. Indian Journal of Agricultural Sciences 84 (6): 684-690.

Global Agri System. 2009. Agriclinics and Agribusiness Centres-Evaluation Study. P (1- 87).

Kanwat, M., Chargotra, M., Kumar, S. and Mishra, B. P., 2011, Attitude of the Agricultural Graduate towards Agriclinic and Agri-business Centers in Arunachal Pradesh, Indian Res. J. Ext. Edu. 11 (1): 117-119.

Karjagi, R., 2006, Economic Performance of Agriclinics and Agribusiness Centres in South India. Ph.D. (Agribusiness Management) Thesis, University of Agricultural Sciences, Dharwad.

Karjagi, R., Khan, H. S. S., Vijaykumar, H. S. and Kunnal, L. B., 2009, Problems of trained agripreuners under the scheme of agriclinics and agribusiness centers in starting and running their agriventures - A study in south India. Karnataka J. Agric. Sci., 22(1): 233-234

Manikandan, M. and Sheik Abdullah, S., 2016, Human Resource Development for Agricultural Sector in India. International Journal of Environment, A griculture and Biotechnology, 1 (4): 723-728.

Parimaladevi, S., Sakeer Husain, A. and Bhaskaran, S., 2006, Determinants of the effectiveness of 'agriclinics and agribusiness centres scheme' in Kerala. Journal of Tropical Agriculture, 44 (12): 91-93.

Rama Rao D, Rashmi Agrawal, Nanda SK, Awasthi IC, Joshi GP, Sanchita Bhattacharya, Indra Kumar D., 2011, Assessment of Future Human Capital Requirements in Agriculture and Allied Sectors. NAIP Project Report, National Academy of Agricultural Research Management, Hyderabad, India. pp 410.

Taufiq, A., Shamsul, H. and Rifat, H., 2016, Analyzing the Constraints Faced by the 
Trained Agri-preneurs under Agriclinics and Agri-business Center Scheme. Journal of Community Mobilization and Sustainable Development, 11 (2): 202-205.

Venkattakumar, R., Chandrashekara, P. and Bharat S. Sontakki, 2016, Critical Success Factors (CSF) for Agri-clinics and Agri-business Centers (AC \& ABC) Scheme in India. Indian Res. J. Ext. Edu. 16 (1), 1-8.

Venkattakumar, R., Chandrashekara, P. and
Sontakki, B. S., 2012, Perception of Agripreneurs towards Nodal Training Institutes. Journal of Extension Education, 24 (3): 4880-4885.

http://www.agriclinics.net/ https://prsindia.org/sites/default/files/parliame nt_or_policy_pdfs/Economic\%20Surve y\%202018-19\%20Summary$\% 20 \mathrm{To} \% 20$ Upload.pdf

https://www.ibef.org/industry/agricultureindia.aspx

\section{How to cite this article:}

Chaitra, G. B., Chidanand Patil and Yeledhalli, R. A. 2020. Attracting and Retaining Youth in Agriculture - A Case of Agriclinics and Agribusiness Centres (ACABC) Scheme in India. Int.J.Curr.Microbiol.App.Sci. 9(02): 1109-1115. doi: https://doi.org/10.20546/ijcmas.2020.902.129 